\title{
Efektivitas Program Bimbingan Karir Berbasis Teori Super untuk Mengembangkan Identitas Vokasional Remaja
}

\author{
Agungbudiprabowo \\ Universitas Ahamad Dahlan, Yogyakarta, Indonesia \\ Email: agungbudiprabowo@bk.uad.ac.id \\ Nurhudaya \\ Universitas Pendidikan Indonesia, Bandung, Indonesia \\ Email: nurhudaya@upi.edu \\ Amin Budiamin \\ Universitas Pendidikan Indonesia, Bandung, Indonesia \\ Email: amin.budiamin@upi.edu
}

(Diterima: 12-April-2018; direvisi: 10-Mei-2018; dipublikasikan: 24-Juni-2018)

\begin{abstract}
Abstrak. The study aims to test the effectiveness of career guidance program to develop vocational identity of students. The study uses a quantitative approach with quasi experimental methods and non-equivalent pretest-posttest control group design. The study was conducted in SMK Muhammadiyah Imogiri Yogyakarta by taking a research subject that is a class XI student who is determined by random cluster sampling technique. An instrument which is used is the scale of vocational identity and observation guidelines. Results showed empirically career guidance program interventions based theory of Super effective to develop vocational identity of students. This research can be a reference for school counselor in developing vocational identity of students in the school especially those who are in adolescence
\end{abstract}

Keywords: career guidance program; super theory; vocational identity; adolescence.

\begin{abstract}
Abstrak. Penelitian bertujuan untuk menguji efektifitas program bimbingan karir untuk mengembangkan identitas vokasional siswa. Penelitian menggunakan pendekatan kuantitatif dengan metode eksperimen kuasi dan non equivalent pretest-posttest control group design. Penelitian dilakukan di SMK Muhammadiyah Imogiri Yogyakarta dengan mengambil subjek penelitian yakni siswa kelas XI yang ditentukan dengan teknik cluster random sampling. Instumen yang digunakan adalah skala identitas vokasional dan pedoman obsevasi. Hasil penelitian menunjukkan secara empirik, intervensi program bimbingan karir berbasis teori Super teruji efektif untuk mengembangkan identitas vokasional siswa. Penelitian ini dapat dijadikan rujukan bagi guru bimbingan dan konseling disekolah dalam mengembangkan identitas vokasional siswa di sekolah khususnya yang berada pada masa remaja
\end{abstract}

Kata kunci: program bimbingan karir; teori super; identitas vokasional; remaja

This is an open access article under the CC BY-NC 4.0 license

(http://creativecommons.org/licenses/by-nc-nd/4.0/).

\section{PENDAHULUAN}

Masa remaja adalah suatu periode transisi dalam rentang kehidupan manusia, yang menjembatani masa kanak-kanak dengan masa dewasa. Perkembangan di masa remaja diwarnai oleh interaksi antara faktor-faktor genetik, biologis, lingkungan, dan sosial (Santrock, 2012 hlm.402). Selama masa kanak-kanak, remaja menghabiskan waktu mereka untuk berinteraksi 
dengan orang tua, kawan-kawan, dan guru, kini tiba waktunya mereka dihadapkan pada perubahan biologis, pengalaman-pengalaman baru, serta tugas perkembangan yang baru. Remaja mulai memilih dan merumuskan peran tertentu dan bersiap-siap untuk memegang posisi yang dipilihnya. Jika perkembangan berjalan dengan baik, remaja akan mengawali tahapan ini dengan perasaan aman. Pada tahap perkembangan identitas ini remaja akan bertanya "siapa aku?" dan ide, pemikiran, atau objek apa yang menurut mereka menggambarkan cara mereka dalam berperilaku. Jika lingkungan tidak mendukung dan remaja merasa sulit mendapatkan peran, remaja akan merasa sulit mendapatkan peran tertentu, mereka mungkin akan mengembangkan identitas yang keliru, suatu kondisi yang disebut oleh Erikson sebagai kekacauan identitas atau kebingungan identitas (identity confusion) (Desmita, 2005).

Pemahaman mengenai identitas diri sangat diperlukan bagi remaja secara holistik sesuai dengan kaidah agama, adat istiadat, serta norma yang dijunjung tinggi dalam masyarakat agar remaja terhindar dari kebingungan peran (role confusion) (Reiter, dkk 2009). Perkembangan identitas selama masa remaja sangat penting karena memberikan suatu landasan bagi perkembangan psikososial dan relasi interpersonal pada masa dewasa (Jones \& Hartmann, 1998). Hal ini diperkuat dengan hasil penelitian Ventegodt dan Merrick (2014, hal.1) yang menyimpulkan bahwa kualitas pemahaman identitas diri remaja menentukan tingkat umum remaja sukses dalam hidup di semua bidang. Oleh sebab itu tugas perkembangan identitas pada remaja menjadi landasan keberhasilan saat memenuhi tugas perkembangan dewasa.

Individu yang berada pada fase remaja akhir dihadapkan pada pemilihan jurusan kuliah atau bila langsung bekerja mereka dihadapkan dengan pilihan bidang pekerjaan yang sesuai kemampuan dan minat mereka. Oleh sebab itu sejak dini mereka diharapkan telah memiliki kesadaran yang mendalam mengenai diri mereka khususnya potensi, minat, cita-cita diri dan mulai merencanakan masa depan. Namun tidak semua remaja berhasil meyakini kemampuan, potensi, cita-cita diri dan telah mulai merencanakan masa depan mereka. Pemahaman tentang identitas diri akan memudahkan remaja untuk memilih jurusan atau pekerjaan yang sesuai dengan minat dan kemampuan mereka agar tidak terjebak pada situasi "salah jurusan" atau pekerjaan yang tidak sesuai dengan bidang ketika lulus nanti. Remaja yang belum mampu menilai kemampuan dan minatnya, menilai peluang yang dapat mereka raih, serta membuat komitmen terhadap pilihan pendidikan dan pekerjaan disebut sebagai remaja yang belum mencapai identitas diri (identity achievement) dalam bidang vokasional yang ideal.

Hasil penelitian yang dilakukan oleh Lestari (2010, hlm. 1) pada remaja yang telah lulus SMA menunjukkan bahwa 33\% siswa berada pada status identitas vokasional achievement (pencapaian identitas) , 18\% siswa memiliki status identitas moratorium (penundaan identitas). Sebanyak 19\% siswa berada pada status identitas foreclosure (pencabutan identitas) dan sisanya sebanyak 34\% siswa berada pada status identitas diffusion (penyebaran identitas).

Penelitian yang dilakukan oleh Nuryanto (2013, hlm.1) terhadap 81 orang mahasiswa Program Studi Pendidikan Sosiologi Tahun Akademik 2012/ 2013 menunjukkan sebagian besar pada kategori foreclosure (pencabutan identitas) dan moratorium (penundaan identitas). Hasil penelitian ini mengindikasikan bahwa mahasiswa belum mencapai tingkat achievement.

Selain itu berdasarkan hasil penelitian yang dilakukan oleh Suyati, Widiharto, Rakhmawati, Maulia (2012, hlm 1) mahasiswa lulusan bimbingan dan konseling yang memperoleh pekerjaan tidak sesuai dengan bidang keilmuan sebanyak (15\%) dan kategori memperoleh pekerjaan sesuai bidang keilmuan sebanyak (85\%). Responden yang bekerja tidak sesuai bidang keilmuan, diantaranya bekerja sebagai wiraswastawan, Karyawan Tata Usaha ataupun ibu rumah tangga.

Lebih lanjut Purwoko, (2002, hlm. 32) yang melakukan survey terhadap mahasiswa di beberapa PTN di Surabaya menemukan $82 \%$ mahasiswa memilih jurusan bukan berdasar pemilihan dan persiapan karir yang telah dilakukan semasa SMU. Masalah karir kongkrit yang dirasakan oleh siswa menurut Supriatna (2009, dalam Juwitaningrum 2010 hal. 65) antara lain: 1) siswa kurang memahami cara memilih program studi yang cocok dengan kemampuan dan minat, 2) siswa tidak memiliki informasi tentang dunia kerja yang cukup, 3) siswa masih bingung memilih pekerjaan, 4) siswa masih kurang mampu memilih pekerjaan yang sesuai dengan kemampuan dan minat,, 5) siswa merasa cemas untuk mendapatkan pekerjaan setelah tamat sekolah, 6) siswa belum memiliki pilihan perguruan tinggi atau lanjutan pendidikan tertentu, jika setelah tamat tidak memasuki dunia 
kerja, 7) siswa belum memiliki gambaran tentang karakteristik, persyaratan, kemampuan, dan keterampilan yang dibutuhkan dalam pekerjaan serta prospek pekerjaan untuk masa depan karirnya.

Paparan di muka memperlihatkan adanya kesenjangan antara kondisi remaja akhir yang idealnya mencapai identitas vokasional, namun faktanya melihat beberapa hasil penelitian yang dipaparkan bahwa masih banyak remaja yang mengalami kebingungan peran identitas khususnya identitas vokasional.

Oleh karena itu perlu suatu upaya bantuan dalam mengembangkan identitas diri remaja spesifik pada identitas vokasional secara utuh. Salah satu upaya bantuan yang bisa diberikan adalah layanan bimbingan karir. Raskin (dalam Archer, 1994, hlm. 155) berpendapat bahwa bimbingan karir dapat digunakan untuk mengembangkan identitas vokasional. Bantuan profesional yang digunakan dalam bimbingan karir harus berfokus pada perkembangan. Karena paradigma status identitas berdasar pada teori perkembangan komprehensif (Erikson, 1968, Waterman, 1982, Marcia, 1993).

Menurut Suherman (2013) bimbingan karir adalah suatu proses membantu seseorang untuk mengerti dan menerima gambaran tentang diri pribadinya dan gambaran tentang dunia kerja di luar dirinya, mempertemukan gambaran diri tersebut dengan dunia kerja itu untuk pada akhirnya dapat memilih bidang pekerjaan, memasukinya dan membina karir dalam bidang tersebut. Sendada dengan pendapat diatas bimbingan karir merupakan salah satu jenis bimbingan yang berusaha membantu individu dalam memecahkan masalah karir, untuk memperoleh penyesuaian diri yang sebaikbaiknya antara antara kemampuan dengan lingkungan hidupnya, memperoleh keberhasilan diri dalam perjalanan hidupnya (Surya, 1988, hlm. 31)

Tujuan bimbingan karir di sekolah menurut Sukardi (1989), adalah agar siswa dapat 1) meningkatkan pengetahuan tentang dirinya sendiri (self concept); 2) meningkatkan pengetahuannya tentang dunia kerja; 3)mengembangkan sikap dan nilai diri dalam menghadapi pilihan lapangan kerja dalam persiapan memsukinya; 4) meningkatkan ketrampilan berpikir agar mampu mengambil keputusan tentang jabatan yang sesuai dengan dirinya dan tersedia dalam dunia kerja; dan 5)menguasai ketrampilan dasar yang penting dalam pekerjaan terutama kemampuan berkomunikasi, bekerja sama, berprakarsa dan lain sebagainya.

Grand Theory perkembangan karir remaja yang digunakan dalam program bimbingan karir berbasis pada teori Super (Sharf, 1992) dalam konsep life stages. Super (Manrihu, 1992) meringkas konsep life stages ke dalam 12 proposisi. Berdasakan 12 proposisi tersebut, Super membagi tahap perkembangan karir menjadi lima tahapan yaitu: a) tahap pertumbuhan (growth); b) tahap eksplorasi (exploration); c) tahap pendirian (establishment); d) tahap pemeliharaan (maintenance); d) dan e) tahap kemunduran (decline) (Osipow, 1983, Manrihu 1986, Sharf, 1992, hlm.169). Menurut pendapat tersebut, maka tahap pekembangan karir remaja berada pada tahap eksplorasi (exploration). Pada tahapan ini pula menurut Savickas (2002, dalam Zunker 2006 hal.60) individu mencari makna dari diri sebagai upaya untuk menentukan identitas vokasional.

Karakteristik perkembangan karir remaja berada pada tahap eksplorasi (usia 15-24 tahun). Tahap eksplorasi ditandai dengan mulai melakukan penelaahan diri (self examination), mencoba membagi berbagai peranan, serta melakukan penjelajahan pekerjaan atau jabatan baik di sekolah, pada waktu senggang, maupun melalui sistem magang.

Dengan adanya program Bimbingan Karir berbasis teori Super yang fokus dalam mengembangkan identitas vokasional (vocational identity) remaja, diharapkan dapat membantu remaja dalam mengembangkan identitias vokasional secara utuh, agar remaja terhindar dari kebingungan peran identitas (role confusion) khususnya peran identitas vokasional.

\section{METODE PENELITIAN}

Pendekatan penelitian yang digunakan dalam penelitian ini adalah kuantitatif. Desain penelitian yang digunakan eksperimen kuasi dengan jenis nonequivalent pre test-post test control group design (pretest-postest dua kelompok).

Penelitian dilakukan di SMK Muhammadiyah Imogiri Yogyakarta, dengan mengambil subjek penelitian yakni siswa kelas XI sejumlah 60 siswa yang terdiri dari dua kelas ditentukan secara random sampling menggunakan teknik cluster random sampling. Instrumen penelitian yang digunakan adalah Identitas Vokasional dan Jurnal Kegiatan. 
Langkah-langkah penelitian mencakup yakni pre test (pengukuran awal), pemberian perlakuan (treatment) dan post test (pengukuran akhir). Teknik analisis data kuantitatif yang digunakan antara lain ukuran gejala pusat dan persentase untuk menganalisis data mengenai gambaran identitas vokasional siswa, uji normalitas, linearitas dan korelasi terhadap pre test, skor post test dan gain score kelompok eksperimen dan kontrol sebagai uji prasyarat, serta uji perbedaan dua rerata antara hasil pre test dan post test yang dianalisis menggunakan $t$-test.

\section{HASIL DAN PEMBAHASAN}

Data hasil penelitian diperoleh melalui penyebaran kuesioner terhadap 60 siswa (30 siswa sebagai kelompok eksperimen dan 30 siswa sebagai kelompok kontrol). Kuesioner yang disebar adalah untuk memperoleh data penelitian terkait profil identitas vokasional siswa kelas XI SMK Muhammadiyah Imogiri. Data penelitian menunjukkan profil sebanyak $20 \%$ siswa berada pada identitas vokasional achievement, $17 \%$ siswa moratorium, $3 \%$ siswa forclosure, dan $60 \%$ siswa diffusion.

Apabila divisualisasikan dalam bentuk gambar, profil identitas vokasional siswa kelas XI SMK Muhammadiyah Imogiri dapat dilihat pada Gambar 1.

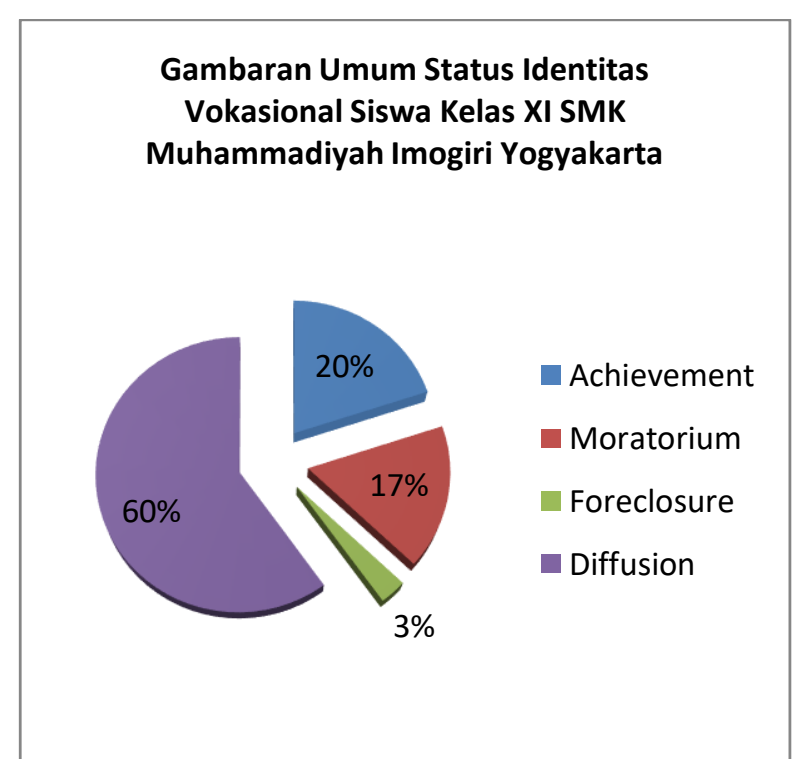

Gambar 1. Gambaran Umum Identitas Vokasional Siswa Kelas XI SMK Muhammadiyah Imogiri

Berdasarkan gambar 1 terungkap bahwa secara umum siswa kelas XI SMK Muhammadiyah Imogiri berada pada status diffusion, dimana pada status ini menunjukkan bahwa siswa masih belum melakukan eksplorasi karir, dan belum memiliki komitmen karir. Siswa belum mencari informasi tentang alternatif vokasional dan belum mencoba untuk menetapkan suatu pilihan vokasional yang akan diambil.

Setelah mengetahui gambaran umum identitas vokasional siswa kelas XI SMK Muhammadiyah imogiri, kemudian dilakukan intervensi berupa program layanan bimbingan karir berbasis teori Super. Setelah dilakukan intervensi kemudian dilakukan post-test, hasil post test menunjukkan perubahan status identitas yang signifikan sebagaimana gambar 2

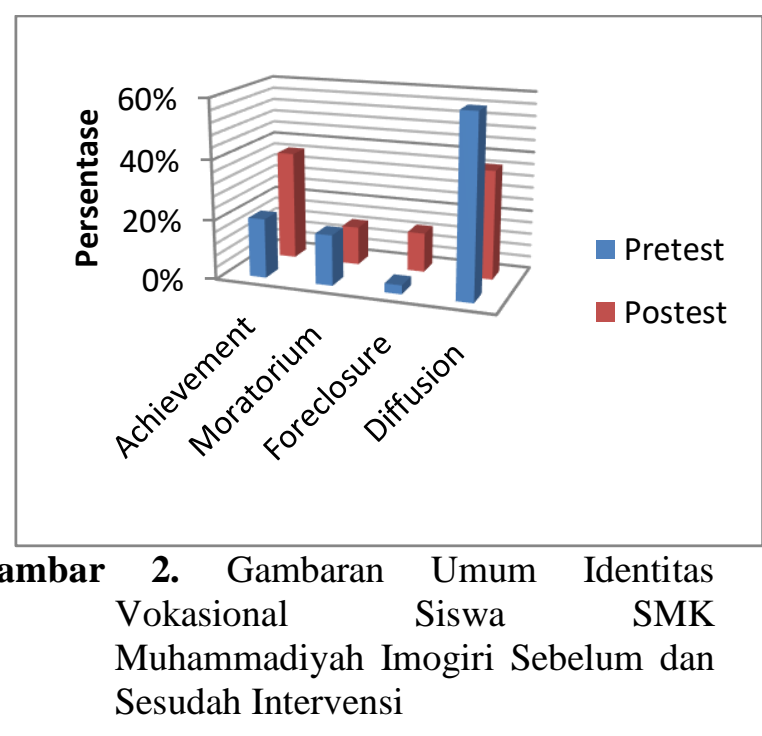

Berdasarkan gambar 2 dapat dilihat bahwa setelah dilakukan intervensi berupa layanan bimbingan karir berbasis teori Super terjadi peningkatan status identitas vokasional. Secara umum siswa kelas XI SMK Muhammadiyah Imogiri sebelum dilakukan intervensi (pre-test) berada pada status identitas diffusion sebesar $60 \%$, kemudian setelah dilakukan intervensi secara umum identitas vokasional siswa berada pada status identitas vokasional achievement sebesar $37 \%$.

Secara keseluruhan terdapat peningkatan dan penurunan yang signifikan identitas vokasional siswa sebelum dengan setelah diberikan intervensi. Sebelum dilakukan intervensi status identitas vokasional achievement sebesar $20 \%$ setelah dilakukan intervensi meningkat menjadi $37 \%$, status identitas vokasional moratorium dari $17 \%$ turun menjadi $13 \%$, status identitas vokasional foreclosure dari 3\% meningkat menjadi $13 \%$ sedangkan status identitas 
vokasional diffusion terjadi penurunan yang signifikan dari $60 \%$ menurun menjadi $37 \%$.

Kemudian untuk mengetahui adanya peningkatan atau penurunan status identitas vokasional sebelum dan sesudah dilakukan intervensi dilihat dari perubahan setiap status identitas maka akan dipaparkan gambaran distribusi status identitas vokasional siswa kelas XI SMK Muhammadiyah Imogiri tahun 2015/ 2016 sebagaimana tabel 2.

Tabel 2. Gambaran Distribusi Status Identitas Vokasional Siswa Kelas XI SMK Muhammadiyah Sebelum dan Sesudah Diberikan Intervensi Berdasarkan Indikator

\begin{tabular}{|c|c|c|c|}
\hline \multicolumn{2}{|c|}{$\begin{array}{l}\text { Status Identitas } \\
\text { Vokasional }\end{array}$} & \multirow[t]{2}{*}{$\begin{array}{l}\text { Frek } \\
\text { uensi }\end{array}$} & \multirow[t]{2}{*}{$\begin{array}{l}\text { Persent } \\
\text { ase } \%\end{array}$} \\
\hline $\begin{array}{l}\text { Pre- } \\
\text { test }\end{array}$ & $\begin{array}{c}\text { Post- } \\
\text { test }\end{array}$ & & \\
\hline $\begin{array}{l}\text { Achiev } \\
\text { ement }\end{array}$ & $\begin{array}{l}\text { Achiev } \\
\text { ement }\end{array}$ & 6 & $20 \%$ \\
\hline $\begin{array}{l}\text { Achiev } \\
\text { ement }\end{array}$ & $\begin{array}{l}\text { Morato } \\
\text { rium }\end{array}$ & 1 & $3 \%$ \\
\hline $\begin{array}{l}\text { Morato } \\
\text { rium }\end{array}$ & $\begin{array}{l}\text { Achiev } \\
\text { ement }\end{array}$ & 4 & $13 \%$ \\
\hline $\begin{array}{l}\text { Forecl } \\
\text { osure }\end{array}$ & $\begin{array}{l}\text { Forecl } \\
\text { osure }\end{array}$ & 1 & $3 \%$ \\
\hline $\begin{array}{l}\text { Diffusi } \\
\text { on }\end{array}$ & $\begin{array}{l}\text { Achiev } \\
\text { ement }\end{array}$ & 2 & $7 \%$ \\
\hline $\begin{array}{l}\text { Diffusi } \\
\text { on }\end{array}$ & $\begin{array}{l}\text { Morato } \\
\text { rium }\end{array}$ & 1 & $3 \%$ \\
\hline $\begin{array}{l}\text { Diffusi } \\
\text { on }\end{array}$ & $\begin{array}{l}\text { Forecl } \\
\text { osure }\end{array}$ & 4 & $13 \%$ \\
\hline $\begin{array}{l}\text { Diffusi } \\
\text { on }\end{array}$ & $\begin{array}{l}\text { Diffusi } \\
\text { on }\end{array}$ & 11 & $37 \%$ \\
\hline \multicolumn{2}{|c|}{ Jumlah } & 30 & $100 \%$ \\
\hline
\end{tabular}

Berdasarkan tabel 2 dapat dilihat bahwa terdapat beberapa kemungkinan perubahan setiap status identitas sebelum dan sesudah dilakukan intervensi. Bagi siswa yang memiliki status identitas diffusion menunjukkan terjadi peningkatan dengan melakukan usaha eksplorasi dan komitmen sehingga berubah pada status identitas achievement,s terdapat 3\% siswa melakukan usaha eksplorasi saja sehingga berubah menjadi moratorium, kemudian siswa yang berkomitmen terhadap alternatif awal berubah menjadi status identitas foreclosure, dan terdapat $37 \%$ siswa yang belum melakukan eksplorasi maupun komitmen karir sehingga tetap berada pada status identitas diffusion.

Terdapat 3\% siswa yang tetap menjadi forclosure menunjukkan bahwa siswa masih mempertimbangkan atau merubah komitmen yang ditetapkannya semula dan belum melakukan eksplorasi. Kemudian pada status identitas moratorium terjadi perpindahan status identitas vokasional siswa sebesar $13 \%$, hal ini menunjukkan bahwa siswa dapat meningkatkan komitmennya sehingga menjadi status identitas achievement. Selanjutnya terdapat $20 \%$ siswa yang dapat mempertahankan dan menaikkan status identitasnya menjadi achievement, kemudian siswa sebesar 3\% memikirkan kembali komitmennya dan berusaha kembali melakukan eksplorasi sehingga menjadi status identitas vokasional moratorium.

Selain data yang dianalisis dengan menggunakan persentase, ada juga data yang di analisis menggunakan uji perbedaan dua ratarata. Analisis tersebut dilakukan untuk menguji hipotesis penelitian yang berbunyi : "Program bimbingan karir berbasis teori Super efektif untuk mengembangkan identitas vokasional remaja." Hipotesis statistiknya adalah sebagai berikut.

$$
\begin{aligned}
& \mathrm{H}_{0}: \mu_{\text {eksperimen }}=\mu_{\text {kontrol }} \\
& \mathrm{H}_{1}: \mu_{\text {eksperimen }}>\mu_{\text {kontrol }}
\end{aligned}
$$

Langkah selanjutnya adalah melakukan analisis statistik untuk mengetahui nilai thitung (melalui uji $\mathrm{t}$ independen atau uji $\mathrm{t}$ berpasangan) dari skor pre test, skor post test dan gain score kelompok kontrol maupun eksperimen. Hasil analisis statistik data penelitian dengan menggunakan uji $\mathrm{t}$ (t-test) dirangkum dalam Tabel 3 berikut. 
Tabel 3. Hasil Uji Beda Postest Kelompok Eksperimen dan Posttest Kelompok Kontrol

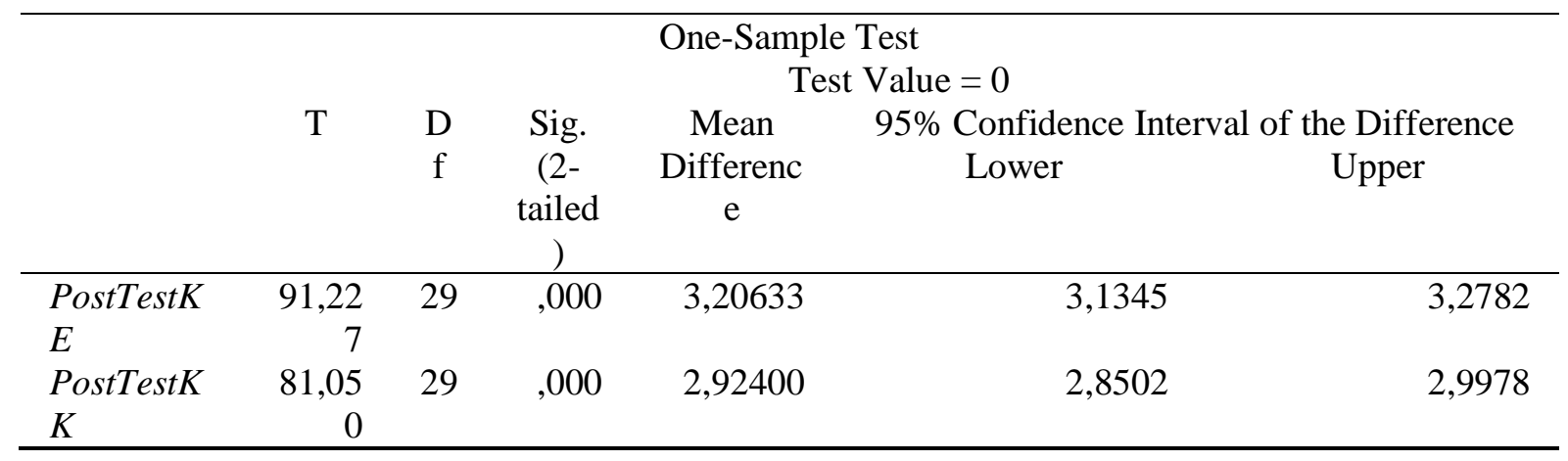

Berdasarkan tabel 3 diperoleh nilai signifikansi $0,000(<0,05)$ pada taraf signifikansi $5 \%(0,05)$ dan rata-rata kelompok eksperimen sebesar 3,2 sedangkan rata-raa pada kelompok kontrol sebesar 2,9. Dapat dimaknai bahwa terdapat perbedaan yang signifikan antara kelompok eksperimen atau kelompok yang diberi program layanan bimbingan karir berbasis teori super dengan kelompok kontrol atau kelompok siswa yang tidak diberi program layanan bimbingan karir berbasis teori Super. Berdasarkan hal tersebut dapat disimpulkan bahwa program bimbingan karir berbasis teori Super efektif untuk mengembangkan identitas vokasional (vocational identity) siswa kelas XI SMK Muhammadiyah Imogiri Yogyakarta

\section{Pembahasan}

Pada hasil penelitian terungkap bahwa siswa kelas XI SMK Muhammadiyah Imogiri memiliki status identitas vokasional achievement sebanyak $20 \%$, moratorium $17 \%$, foreclosure $3 \%$, dan diffusion $60 \%$, dari data tersebut dapat dilihat bahwa siswa kelas XI SMK Muhammdiyah Imogiri berada pada status identitas vokasional diffusion. Secara umum siswa masih belum melakukan eksplorasi karir, dan belum memiliki komitmen karir. Mereka belum mencari informasi tentang alternatif vokasional dan belum mencoba untuk menetapkan suatu pilihan vokasional yang akan diambil.

Menurut Archer (1993, hlm. 187) bahwa remaja mengalami kesulitan dalam melakukan eksplorasi dan menetapkan komitmen karena adanya beberapa halangan, antara lain kegagalan dalam mata pelajaran yang berhubungan dengan vokasional yang diinginkan, kekurangan kondisi fisik dan hambatan dalam hubungan kehidupan sosial.

Identitas Diffusion sebenarnya dapat berubah dan masih terbuka untuk berbagai kemungkinan dan pengaruh, karena belum terbentuk struktur kepribadian yang kuat. Sebagaimana yang disebutkan oleh Marcia (1993, hlm. 10) bahwa karakteristik individu yang mengalami identitas diffusion adalah individu yang kurang memiliki konsep diri yang kokoh. Individu juga menunjukkan tingkat kecemasan dan tegangan internal yang tinggi. Kemudian tidak memiliki definisi yang jelas tentang siapa dirinya dan tidak dapat memperkirakan ciri dan sifat kepribadian yang dimiki.

Identitas vokasional diffusion ditujukan pada peserta didik yang belum melakukan eksplorasi dalam pembentukan identitas. Siswa cenderung minim pengetahuan yang mendalam yang ditunjukkan oleh rendah dalam keluasan dan kedalaman informasi yang dihimpun tentang berbagai alternatif dalam pembentukan identitas. Seperti yang diungkapkan Marcia \& Archer (1993, hlm. 206). Aspek ini dapat meliputi kedalaman pengetahuan dan pemahaman individu tentang alternatif yang ada dalam pencapaian idntitas, serta adanya penilaian yang dilakukan individu mengenai kriteria pilihan yang diinginkan dan penilaian mengenai kemampuan diri untuk mengambil pilihan tersebut.

Individu yang berada pada status identitas vokasional diffusion memiliki kecenderungan kurang melakukan aktifitas terarah untuk mengumpulkan informasi yang menyangkut semua aktifitas yang dipandang tepat untuk mencari dan mengumpulkan informasi yang dibutuhkan. Menurut Marcia \& Archer (1993, hlm. 206) bahwa aktivitas ini dapat berupa introspeksi diri, observasi orang lain, bertanya pada orang yang menjadi sumber informasi seperti orang tua, saudara, guru, atau bahkan dengan membaca buku dan menonton televisi.

Faktor lain yang membuat individu belum bereksplorasi dalam bidang vokasional adalah 
kurangnya individu dalam mempertimbangkan berbagai informasi yang telah dimiliki tentang berbagai kemungkinan dan peluang dari setiap alternatif yang ada. Marcia \& Archer (1993, hlm. 207) menyebutkan bahwa individu harus menyadari keberadaan alteratif-alternatif yang berlawanan mengenai jurusan yang akan dipilihnya nanti, pertimbangan dari remaja mengenai peluang kelebihan dan kekurangan alternatif-alternatif yang ada sebelum memutuskan suatu pilihan dalam pembentukan identitas, dan pertimbangan individu mengenai konsekuensi yang terdapat dalam pilihannya tersebut.

Individu yang melakukan eksplorasi dalam bidang vokasional pastinya memiliki keinginan untuk membuat keputusan secara dini yang ditunjukkan oleh sejauhmana individu memiliki keinginan dalam memecahkan keraguan atau ketidakjelasan secepat mungkin secara realistis dan meyakini apa yang dipandang tepat bagi dirinya. Namun bagi yang memiliki status identitas vokasional diffusion, mereka memiliki kecenderungan menunda keinginan membuat keputusan karena belum melakukan berbagai aspek eksplorasi lain (Marcia \& Archer, 1993, hlm. 207).

Selanjutnya melihat hasil penelitian yeng disajikan dalam tabel 4.1 , terdapat $20 \%$ siswa yang sudah memiliki identitas achievement. Telah dikemukakan Archer (1993, hlm. 191) bahwa remaja berstatus identitas vokasional achievement adalah remaja yang telah berhasil menetapkan pilihannya dalam hal vokasional dan menunjukkan komitmennya pada pilihan tersebut. Marcia, dkk. (1993, hlm. 213) menyebutkan bahwa remaja yang telah mengalami tahap achievement pada bidang vokasional adalah remaja yang telah berpengalaman menyelesaikan suatu periode krisis mengenai nilai-nilai dan pilihan-pilihan hidup mereka serta mereka telah memiliki komitmen atas pilihan tersebut.

Archer (1993, hlm.191) berpendapat bahwa beberapa remaja yang telah mencapai tahapan status identitas vokasional achievement, ada yang secara fleksibel dalam menetapkan pilihan vokasionalnya, hal ini dapat dimaknai bahwa remaja menyiapkan alternatif lain akan penentuan vokasionalnya. Akan tetapi ada juga sebagian remaja yang berstatus identitas vokasional achievement yang kurang fleksibel dalam menentukan pilihannya, hal ini dimungkinkan mereka rentan mengalami kecemasan dalam menentukan pilihan pada masa tertentu.

Dalam hal penentuan jenjang pendidikan yang lebih tinggi ataupun bekerja, Archer (1993, hlm. 191) mencontohkan siswa SMA atau SMK yang telah menentukan jurusan yang akan diambil pada saat kuliah ataupun memilih pekerjaan. Mereka yang telah mencapai status identitas vokasional achievement dimungkinkan belum bisa membuat membuat komitmen terhadap perkuliahannya atau pilihan pekerjaanya itu, akan tetapi saat mereka SMA atau SMK telah melakukan aktivitas-aktivitas yang mengarahkan pada peningkatan pengetahuan akan jurusan yang hendak mereka pilih, seperti menggeluti hobi yang berhubunga, bekerja paruh waktu, dan melakukan diskusi dengan orang-orang yang sebelumnya atau sedang berkerja atapun berkuliah dijurusan yang hendak mereka pilih.

Lebih lanjut siswa yang memiliki identitas vokasional achievement memiliki eksplorasi dan komitmen karir yang tinggi. Menurut Marcia \& Archer (1993, hlm.206) eksplorasi yang tinggi menunjukkan kedalaman pengetahuan dan pemahaman remaja tentang alternaif yang ada dalam pencapaian identitas, adanya penilaian yang dilakukan remaja mengenai kriteria pilihan yang diinginkan dan penilaian mengenai kemampuan diri untuk mengambil pilihan tersebut; melakukan aktivitas yang terarah untuk mengumpulkan informasi yang menyangkut semua aktivitas yang dipandang tepat untuk mencari dan mengumpulkan informasi yang dibutuhkan; mampu mempertimbangkan berbagai informasi yang telah dimiliki sebagai kemungkinan dan peluang dari setiap alternatif yang ada; menunjukkan rasa senang, bangga, dan bersemangat pada saat menggali informasi mengenai alternatif pilihan dalam pembentukan identitasnya; dan keinginan untuk membuat keputusan secara dini yang ditunjukkan oleh sejauhmana individu memiliki keinginan untuk memecahkan keragu-raguan atau ketidakjelasan secepat mungkin secara realistis dan meyakini apa yang dipandang tepat bagi dirinya.

Dimensi lain yakni komitmen, Marcia \& Archer (1993, hlm. 208) menyebutkan bahwa komitmen yang tinggi dapat dilihat dari pengetahuan yang mendalam terperinci dan akurat tentang hal-hal yang telah diputuskan; adanya aktivitas yang terarah untuk mengumpulkan informasi yang menyangkut semua aktivitas yang dipandang tepat untuk mencari dan mengumpulkan informasi yang dibutuhkan; menunjukkan perasaan tenang dan 
stabil sebagai ekspresi diri keyakinannya terhadapa keputusan yang telah mereka ambil; mampu mengidentifikasi orang-orang yang dianggap penting dengan sejauhmana remaja mampu membedakan aspek positif dan negatif dari figur yang dianggap ideal; dapat memproyeksikan dirinya ke masa depan dengan ditandai oleh kemampuan pertautkan rencananya dengan aspek lain dalam kehidupan masa depan yang mereka cita-citakan; dan memiliki ketahanan terhadap godaan yang bermaksud untuk mengalihkan keputusan yang telah mereka tetapkan.

Selajutnya berdasarkan hasil penelitian pada tabel 4.1 terdapat $17 \%$ siswa yang berstatus identitas vokasional moratorium. Menurut Archer (1993, hlm. 189) menyebutkan bahwa remaja yang berada pada kelompok ini sedang melakukan pertimbangan akan kelebihan dan kekurangan dari beberapa pilihan vokasional. Informasi didapat remaja melalui diskusi dengan orang tua, guru, konselor, dan teman sebaya.

Siswa yang berstatus identitas vokasional moratorium menunjukkan bahwa mereka sudah melakukan kegiatan eksplorasi karir namun belum membuat sebuah komitmen karir. Siswa belum memiliki pengetahuan yang cukup dengan menunjukkan keluasan dan kedalaman informasi yang berhasil dihimpun tentang berbagai alternatif pilihan dalam pembentukan identitas. Siswa sudah melakukan pencarian informasi dari berbagai sumber informasi tetapi belum mengimplementasikan asebagaktivitas terarah dalam pengumpulan informasi yang menyangkut semua aktivitas yang dipandang tepat untuk mencari dan mengumpulkan informsi yang dibutuhkan, belum mampu mengidentifikasi orang-orang yang dianggap penting atau menjadi figur yang dianggapnya ideal sebagai role model, dan rentan terhadap godaan yang bermaksut untuk mengalihkan keputusan yang telah mereka tetapkan.

Menurut Erikson (dalam Santrok, 2007, hlm. 191) bahwa remaja memang akan mengalami psychososial moratorium, yaitu istilah Erikson mengenai remaja sebagai bagaian dari eksplorasi identitasnya. Istilah ini disebutkan sebagai kesenjangan antara rasa aman yang terjadi di masa kanak-kanak dan otonomi di masa dewasa. Siswa yang berada pada identitas vokasional moratorium penting bagi mereka untuk meningkatkan kemampuan dalam membuat komitmen.

Selanjutnya status identitas vokasional diperoleh dalam penelitian ini adalah status foreclosure dengan persentase 3\%. Dapat dimaknai bahwa siswa telah menentukan pilihan vokasional atau telah membuat komitmen akan tetapi belum melakukan eksplorasi untuk mengetahui secara mendalam mengenai pilihan tersebut. Seperti yang dikemukakan Archer (1993, hlm. 188) bahwa remaja pada tahap ini telah berkomitmen pada satu pilihan vokasional tanpa mempunyai pengetahuan yang jelas mengenai pilihan tersebut. Menurut Steinberg (1993, hlm. 199) biasanya pilihan remaja berstatus identitas vokasional forclosure merupakan pilihan dari orang tua, guru, atau teman dekatnya.

Siswa yang memperoleh status identitas vokasional foreclosure menunjukkan rendah pada dimensi eksplorasi. Siswa belum melakukan aktivitas yang secara aktif untuk mencari informsi atau alternatif pilihan vokasionalnya, belum menggunakan kemampuan, akal, dan potensi yang dimiliki untuk memperoleh pemahaman yang baik tentang alternatif voksionalnya. Siswa denggan status identitas forclosure dikhawatirkan tidak berhasil dalam mengatasi krisis atau eksplorasi sebagaimana disebutkan Erkson (dalam Santrok, 2007, hlm. 191), bahwa remaja yang gagal dalam mengatasi segala persoalan identitas atau masa krisis, maka remaja akan mengalami identity confusion atau kebingungan identitas.

Oleh karena itu, sebagai upaya dalam mengembangkan identitas vokasional siswa SMK Muhammadiyah Imogiri peneliti menggunakan program layanan bimbingan karir berbasi teori Super. Program bimbingan karir perkembangan berbasi teori Super digunakan berdasarkan pertimbangan Raskin (dalam Archer, 1994, hlm. 155) yang berpendapat bahwa bimbingan karir dapat digunakan untuk mengembangkan identitas vokasional. Bantuan profesional yang digunakan dalam bimbingan karir harus berfokus pada perkembangan. Karena paradigma status identitas berdasar pada teori perkembangan komprehensif (Erikson, 1968, Waterman, 1982, Marcia, 1993).

Setelah dilakukan intervensi berupa program layanan bimbingan karir berbasis teori Super untuk mengembangkan identitas vokasional pada siswa kelas XI SMK Muhammadiyah Imogiri, hasil penelitian menunjukkan bahwa terjadi peningkatan yang signifikan antara sebelum diberikan layanan bimbingan karir dengan setelah diberikan layanan bimbingan karir. Lebih lanjut terjadi peningkatan yang signifikan pula antara kelompok siswa yang diberi program 
layanan bimbingan karir berbasis teori Super dengan kelompok siswa yang tidak diberikan program layanan bimbingan karir berbasi teori Super.

Menurut Santrok (2007, hlm. 194) resolusi isu identitas pada masa remaja tidak berarti identitas akan stabil sepanjang hidup seseorang. Sedangkan seseorang yang mengembangkan suatu identitas yang sehat akan bersikap fleksibel, adaptif, dan terbuka terhadap perubahan-perubahan dalam masyarakat, hubungan, dan vokasional. Keterbukaan ini dapat menentukan banyaknya reorganisasi gambarangambaran identitas sepanjang hidup seseorang yang telah mencapai identitas. Banyak peneliti status identitas yakin bahwa pola umum individu yang mengembangkan identitas-identitas yang positif mengikuti apa yang disebut sebagai siklus "MAMA" moratorium-achiever-moratoriumachiever (Archer, 1989, hlm. 121). Siklus ini dapat diciptakan sepanjang hidup (Santrock, 2007; Francis, dkk, 1989).

Program bimbingan karir berbasis teori Super diberikan kepada siswa sebagai upaya dalam menumbuhkan fleksibilitas dan keterampilan yang diperlukan untuk menjajaki berbagai alternatif pilihan vokasional dan mengembangkan komitmen atas pilihan tersebut. Fleksibilitas dan ketrampilan yang dimiliki siswa dapat digunakan sebagai bekal dalam menumbuhkan identitas vokasional sepanjang rentang kehidupan, karena gambaran identitas vokasional yang ditampilkan oleh siswa kelas XI SMK Muhammadiyah Imogiri tidak bersifat permanen.

Sebagaimana yang dikemukakan oleh Marcia (1993, hlm. 22) bahwa setiap kategori yang sudah dicapai tidak bisa bersifat permanen, dan dapat berubah seiring dengan perkembangan orang. Sejak masa remaja dan masa berikutya, akan semakin banyak orang berkategori moratorium atau achievement (papalia, dkk., hlm. 592). Namun, banyak orang bahkan orang dewasa awal, yang masih berada pada kategori foreclosure dan diffusion (Kroger, 1993, hlm. 91).

Menurut penjelasan dari Watermar (1993, hlm. 43) terdapat tiga kemungkinan perubahan setiap status identitas. Bagi orang yang memiliki status identitas diffusion: (a) dapat meningkat dengan melakukan usaha eksplorasi sehingga berubah pada status identitas moratorium, (b) dapat berubah dengan menetapkan atau berkomitmen terhadap alternatif awal, maka berubah menjadi status identitas foreclosure, (c) tetap dalam status identitas diffusion.

Status identitas vokasioanal foreclosure: (a) dapat mempertimbangkan atau merubah komitmen yang ditetapkannya semula, (b) tetap menjadi foreclosure atau (c) turun pada status diffusion jika dia tidak melakukan kmitmen yang baru untuk mengganti yang sebelumnya. Status identitas moratorium: (a) dapat meningkatkan komitmennya sehingga menjadi status identitas achievement (b) berhenti melakukan eksplorasi, atau (c) menghentikan eksplorasi alternatif sehingga menjadi status identitas diffusion. Status identitas vokasional achievement: (a) dapat mempertahankan status identitasnya, (b) memikirkan kembali menjadi moratorium, atau (c) mengalami penurunan ke status identitas diffusion jika tidak menemukan komitmen yang baru.

Berdasarkan hasil penelitian menunjukkan bahwa setelah dilakukan intervensi berupa program layanan bimbingan karir berbasi teori Super, siswa yang berada pada status identitas vokasional diffusion menurun dari $60 \%$ menjadi $33 \%$ hal ini menunjukkan bahwa siswa melakukan usaha eksplorasi sehingga berubah pada status identitas moratorium ataupun siswa memiliki komitmen karir kemudian berada pada status identitas vokasional foreclosure yang dibuktikan dengan meningkatnya identitas foreclosure dari $3 \%$ menjadi $13 \%$. Selain itu hasil penelitian juga menunjukkan bahwa masih terdapat 33\% siswa yang masih berada pada status identitas diffusion hal ini menunjukkan bahwa siswa masih belum melakukan eksplirasi dan komitmen karir. Namun demikian penelitian menunjukkan terjadi peningkatan sigifikan siswa yang memiliki status identitas achievement dari $20 \%$ menjadi $37 \%$.

Kecenderungan siswa yang berada pada status identitas vokasional achievement setelah diilakukan intervensi berupa program layanan bimbingan karir berbasis teori Super menunjukkan bahwa program bimbingan karir berbasis teori Super efektif untuk mengembangkan identitas vokasional siswa sebagaimana yang dikemukakan oleh Raskin (dalam Archer, 1994, hlm. 155) yang berpendapat bahwa bimbingan karir dapat digunakan untuk mengembangkan identitas vokasional. Bantuan profesional yang digunakan dalam bimbingan karir harus berfokus pada perkembangan. Karena paradigma status identitas berdasar pada teori perkembangan komprehensif (Erikson, 1968, Waterman, 1982, 
Marcia, 1993). Namun pada hakikatnya, tidak bisa dipungkiri bahwa siswa yang berada pada status identitas vokasioan achievement akan berubah-ubah sepanjang tahap perkembangan individu tersebut.

Perubahan status identitas dapat terjadi karena pembentukan identitas dapat dipengaruhi oleh bebarapa faktor. Seperti seperti yang diungkapkan Marcia (Papalia, dkk., 2008, hlm. 591) bahwa pembentukan identitas dipengaruhi oleh faktor keluarga dan kepribadian, diantaranya: faktor keluarga (1) identity achievement, yaitu adanya dukungan orang tua yang positif, perhatian dan mempercayai anak; (2) identity moratorium, orang tua tidak punya aturan yang jelas. Anak bingung terhadap otoritas orang tua; (3) identity foreclosure, orang tua tidak menerima sikap dan perasaan anak, orang tua tidak mendengarkan keluhan dan keinginan anak, (4) identity diffusion, orang tua permisif, tidak berwibawa dan tidak memverikan arahan bimbingan dengan baik. Selanjutnya faktor kepribadian: (1) identity achievement, yaitu anak punya kekuatan ego, kemandirian, kontrol diri internal, akrab, percaya diri, inisiatif, kreatif dan berprestasi; (2) identity moratorium, anak cemas, takut gagal, egois, kurang percaya diri, harga diri/ konsep diri rendah; (3) identity forclosure, anak tergantung, kontrol diri eksternal, cemas, tidak percaya diri; (4) identity diffusion, perkembangan konsep diri terlambat, kemampuan kognitif tidak berfungsi dengan baik, ragu-ragu pasif tidak inisiatif.

\section{SIMPULAN DAN SARAN}

Penelitian program bimbingan karir berbasis teori super untuk untuk mengembangkan identitas vokasional siswa dapat disimpulkan bahwa gambaran umum identitas vokasional siswa sebelum dilakukan inervensi berada pada kategori diffusion, setelah diberi intervensi meningkat menjadi achievement. Secara umum program bimbingan karir berbasis teori Super efektif untuk mengembangkan identitas vokasional siswa kelas XI SMK Muhammadiyah Imogiri.

Program bimbingan karir berbasis teori Super untuk mengembangkan identitas vokasional siswa dapat dijadikan guru bimbingan dan konseling sebagai pedoman dalam membimbing siswa bereksplorasi, memiliki komitmen karir sampai pada pencapaian identitas (achievement identity). Pemahaman tentang identitas vokasional akan sangat membantu siswa dalam menjalani perkembangan karir scara optimal, sehingga terhindar dari kebingungan identitas vokasional (identity confusion) pada saat memasuki remaja akhir. Sehingga diharapkan melalui program bimbingan karir berbasis teori Super mampu membantu lulusan SMK menemukan identitas karir mereka.

\section{DAFTAR RUJUKAN}

Desmita. 2005. Psikologi Perkembangan. Bandung: Rosda.

Erikson, E.H. (1974). Identity: Youth and Crisis. London: Whitstable Litho Straker Brothers Ltd.

Juwitaningrum, Ita. 2013. Program Bimbingan Karir Untuk Meningkatkan Kematangan Karir Siswa Smk. PSIKOPEDAGOGOA Jurnal Bimbingan dan Konseling, Vol 2(2), 132-147

Kroger, J. 2000. Identity development: Adolescence through adulthhood. Newbury Park, CA: Sage

Marcia, J. E., Waterman, A S., Matteson, D. R, Archer S. L, \& Orlofslcy, J. L.(Eds.). 1993. Ego identity: A handbook for prychosocial research. New York: Springer.

Nuryanto, Iis L. 2013. Program Bimbingan Pribadi Untuk Mengembangkan Identitas Diri Mahasiswa Tahun 2012/2013). Thesis: UPI

T Suyati, CA Widiharto, D Rakhmawati, D Maulia. 2011. Jurnal Penelitian Psikologi Pendidikan dan Bimbingan, 2(1).

Reiter, P.L, Katz, M.L., Ferketich, A.K, Ruffin. (2009). Appalachian Self Identity Among Women in Ohio. Journal of Rural Community Psychology, E12(1), 1-15.

Santrock, J.W. (2010). The Adolescent: Development, Relationships, and Culture. New York: McGraw-Hill

Sharf, R.S. (1992). Applying Career Development Theory to Counseling California: Brooks/ Cole Publishing Company

Suherman, Uman. (2013). Bimbingan dan Konseling Karir: Sepanjang Rentang Kehidupan. Bandung: Rizqi Press. 
Agungbudiprabowo; Nurhudaya; Budiamin. Program Bimbingan Karir... $\mid 24$

Surya, M. (1988). DasarOdasar Konseling Pendidikan (Konsep dan Teori). Bandung: Bhakti Winaya

Steinberg, L. (2011). Adolscence. New York: McGraw-Hill.

Ventegodt, S and Merrick, J. 2014. Significance of self-image and identity in youth development. Int Journal Child Adolescence Health

Yusuf, Syamsu. 2012. Psikologi Perkembangan Anak \& Remaja. Bandung: Rosda.

Zunker, Vernon G. 2006. Career Counseling A Holistic Aproach 7th Edition. USA: Thomson Brooks/Cole. 